\title{
Menores Estrangeiros não Acompanhados / Unaccompanied Minors
}

https://doi.org/10.21814/uminho.ed.36.42

Reena Mary George

Uni Wien - University of Vienna \& United Nations Office on Drugs and Crime (UNODC), Austria 



\section{Menores Estrangeiros não Acompanhados}

O Comité dos Direitos da Criança (CDC) da Organização das Nações Unidas (ONU) define como menores estrangeiros não acompanhados (MENA) as crianças que foram separadas dos pais, familiares ou que não estão acompanhadas de um responsável ou tutor decretado por lei. Frequentemente, os termos "crianças não acompanhadas" e "crianças separadas" são utilizados de maneira permutável (CDC, Comentário Geral N. ${ }^{\circ} 6$, parágrafos 7 e 8). De acordo com as tendências recentemente identificadas pelo Alto Comissariado das Nações Unidas para os Refugiados (ACNUR), em 2018 havia cerca de 138.600 MENA. Aproximadamente 27.600 MENA solicitaram asilo em cerca de 60 países. Os dados do Eurostat demonstram que cerca de 14.000 MENA procuraram asilo na União Europeia em 2019 sendo a maioria oriunda do Afeganistão, Síria, Paquistão, Somália, Guiné e Iraque. Nos EUA, 76.020 MENA foram detidos nas proximidades ou na fronteira entre EUA-México no ano de 2019. A maioria era oriunda do México, Guatemala, Honduras e El Salvador. De acordo com o ACNUR, entre as principais razões pelas quais as crianças viajam sozinhas estão a pobreza, as catástrofes naturais, a fuga à violência, abuso, guerras e conflitos duradouros, discriminação e perseguição, a expectativa de uma vida melhor, a reunificação familiar. Outros encontram-se na condição de vítimas de tráfico de seres humanos destinados à exploração sexual e/ou laboral ou a serviços forçados.

Existem várias diretrizes legais e mecanismos sociais de proteção que defendem os direitos específicos dos MENA. A mais relevante é a Diretriz do ACNUR para Crianças não Acompanhadas Solicitantes de Asilo (fevereiro 1997) e o Comentário Geral sobre Tratamento das Crianças Não Acompanhadas e Separadas Fora do País de Origem do Comité dos Direitos da Criança (CRC/GC/2005/6). Estas diretrizes promovem o debate e a tomada de consciência sobre as necessidades especiais dos MENA, destacam a importância de uma abordagem compreensiva sobre a sua situação específica, incluindo o acesso ao procedimento de asilo, as garantias legais em relação aos direitos de asilo, a reunificação familiar, o retorno e outras respostas duradouras.

As políticas públicas para a infância e a legislação na União Europeia (UE) referentes aos MENA incorporam orientações da Convenção sobre os 
Direitos da Criança das Nações Unidas (1989) e da Convenção Relativa ao Estatuto do Refugiado das Nações Unidas, de 1951. Além da Resolução do Conselho Europeu, de 26 de junho de 1997, relativa aos menores não acompanhados nacionais de países terceiros (97/C 221/03), da Diretiva 2003/9/ CE do Conselho, de 27 de Janeiro de 2003, que estabelece normas mínimas em matéria de acolhimento dos requerentes de asilo nos Estados-Membros, o Plano de Ação do Conselho da Europa sobre Crianças Migrantes na Europa (2017-2019) propõe apoio concreto aos Estados-Membros em todas as fases do processo de migração. Nos Estados Unidos da América, a legislação relacionada com o tratamento e procedimentos administrativos dos MENA são guiadas por dois estatutos (Ato de Reautorização de Proteção às Vítimas de Tráfico de 2008, P.L. 110 - 457 e o Ato de Segurança Interna de 2012, P.L. 107-296) e um acordo legal (Acordo Flores, de 1997). 0 Acordo Flores estabeleceu limites de tempo e as condições sob as quais as crianças podem ser detidas no âmbito de processo de imigração. Em setembro de 2018, foi implementada a política de "tolerância zero" visando o controlo de travessia ilegal da fronteira que efetivamente separou milhares de crianças de seus pais e as reclassificou como "menores não acompanhados". Foi também proposta regulamentação que visou rescindir as salvaguardas legais estabelecidas no Acordo Flores.

Em 2019, o estudo global da ONU sobre Crianças Privadas de Liberdade (A/74/136, parágrafos $56,91,123$ ) reconheceu que a detenção de crianças por motivos de migração não pode ser considerada como uma medida de último recurso e nunca serve o superior interesse da criança. $O$ estudo recomenda que aos MENA devem ser providos cuidados alternativos em acomodações e equipamentos adequados, segundo as diretrizes da ONU para Cuidados Alternativos para Crianças (A/RES/64/142). Além disso, os Estados devem fornecer às crianças refugiadas acesso aos procedimentos de asilo, outra proteção apropriada, assistência humanitária, incluindo a possibilidade de reunificação familiar, acesso a educação e cuidados de saúde.

Os recentes desenvolvimentos (2020) nos Estados-Membros da UE em relação aos MENA indicam progressos na adoção de políticas nacionais nas quais é defendido o interesse superior da criança. Estas variam entre a adoção de legislações progressivas (Grécia, Espanha, Chipre), a relocação de menores da Grécia para outros Estados-Membros (Luxemburgo, Finlândia, Alemanha), a atribuição de autorizações de residência ( 569 nos Países Baixos) ou a construção de equipamentos específicos para o seu acolhimento (Portugal). Nos EUA, existem aproximadamente 5.000 MENA sob custódia do Gabinete de Realocação de Refugiados (GRR) que imediatamente coloca 
uma criança num ambiente menos restritivo atendendo ao seu superior interesse e atendendo ao perigo existente para si, para a comunidade bem como do seu potencial risco de fuga. Há ainda a informação de que o Governo dos EUA fornecerá assistência financeira de 2.9 milhões de dólares à Grécia para melhorar as condições de vida destas crianças, apoiando diretamente as ilhas gregas [onde se localizam os centros de refugiados] no combate contra a pandemia de COVID-19.

Há progresso e um crescente reconhecimento da promoção de mecanismos de proteção para MENA. Todavia, muito há, ainda, por fazer. Vários artigos relatam a separação de crianças, mantidas em detenção ou "estando sozinhas" até que completem os 18 anos de idade. A atual pandemia do COVID-19, reforçou as vulnerabilidades destes grupos de crianças. A readaptação e reintegração destas crianças deve constituir uma prioridade quando se promove o debate sobre políticas para grupos vulneráveis, de modo a que o objetivo da Agenda de Desenvolvimento 2030 das Nações Unidas de "transformar o mundo" na realidade "não deixe ninguém para trás".

(Tradução de Luana Dias Gonzaga )

\section{Unaccompanied Minors}

The United Nations (UN) Committee on the Rights of the Child (CRC) defines unaccompanied minors (UAM) as children who have been separated from both parents and other relatives and are not being cared for by an adult to whom they were attributed by law. Frequently, the terms unaccompanied and separated children are used inter-changeably (Committee on the Rights of the Child, General Comment No.6 (2005), p. 7-8). According to The UN High Commissioner for Refugees (UNHCR) recent trends (2018), there were around 138,600 UAMs. Almost 27,600 UAMs applied for asylum in at least 60 countries. The Eurostat data affirms that almost 14,000 UAMs sought asylum in the European Union in 2019, most coming from Afghanistan, Syria, Pakistan, Somalia, Guinea and Iraq. In the United States of America (USA), 76,020 UAMs were apprehended at or near the USA-Mexico border in 2019. Most of them were from Mexico, Guatemala, Honduras, and El Salvador. According to UNHRC, the reasons for children travelling on their own include poverty; natural catastrophes; escaping violence; abuse; long-standing war or conflicts; discrimination; persecution; expectation of a better life; joining family members; victims of trafficking destined for sexual exploitation and/or forced labour or services. 
There are various socio-legal guidelines that uphold the rights and protection mechanisms for UAMs. The most prominent are the UNHCR Guideline on Unaccompanied Children Seeking Asylum (February 1997) and General Comment on Treatment of Unaccompanied and Separated Children Outside their Country of Origin (CRC/GC/2005/6). These guidelines promote awareness of special needs of UAMs and highlight the importance of a comprehensive approach; they also stimulate discussions on the needs of UAMs including access to the asylum procedure, legal safeguards and rights in asylum, as well as family reunification, return and other forms of durable solutions.

Laws in the European Union (EU) regarding UAMs are reflected in the EU acquis. The EU has incorporated aspects of CRC, 1989 and the UN Refugees Convention, 1951 in its policies and legislation. Further, the European Council Resolution (97/C 221/03) of 1997, the Council Directive 2003/9/ EC, and the Council of Europe Action Plan on Migrant Children in Europe (2017-2019) propose concrete support to Member States at all stages of the migration process. In the United States (US) laws related to treatment and administrative processing of UAMs is guided by two statutes [Trafficking Victims Protection Reauthorization Act of 2008 (P.L. 110-457), the Homeland Security Act of 2002 (P.L. 107-296)] and a legal settlement (Flores Settlement Agreement of 1997). The Flores Settlement Agreement set limits on the length of time and conditions under which children can be incarcerated in immigration detention. In September 2018, a "zero tolerance" policy was implemented targeting illegal border crossing that effectively separated thousands of children from their parents and reclassified them as "Unaccompanied Children". It also proposed regulations that seek to terminate the Flores Settlement Agreement's legal safeguards.

In 2019, the UN Global Study on Children Deprived of Liberty (A/74/136, para $56,91,123)$ recognized that migration-related detention of children cannot be considered as a measure of last resort and is never in the best interest of the child. The study recommends that UAMs should be provided with alternative care and accommodation, in line with the UN Guidelines for the Alternative Care of Children (A/RES/64/142). Further, States should provide refugee children with access to asylum procedures; other appropriate protection; humanitarian assistance, including family reunification, education and health care.

The recent developments (2020) in the EU Member States in case of UAMs indicate progress towards adopting policies which uphold the best interest 
of the child. These range from adopting progressive legislations (Greece, Spain, Cypress), to relocating minors from Greece to other Member States (Luxembourg, Finland, Germany), to 569 UAMs receiving resident permits (Netherlands), or building residential care for children, including UAMs (Portugal). In the US, there are approximately 5,000 UAMs in the custody of the Office of Refugee Resettlement (ORR) which promptly places an UAM in the least restrictive setting that is in the best interest of the child, taking into consideration danger to self, danger to the community, and risk of flight. There are also news reports that the US government will provide 2,9 million USD in financial assistance to Greece to improve the living conditions of UAMs and support the islands against the COVID-19 pandemic.

There is progress and growing recognition in terms of enhancing protective mechanisms for UAMs, yet much remains to be achieved. Several articles report separation of children, being held in detention, or "being on their own" once they attain 18 years of age. The current COVID-19 pandemic has reinforced the existing vulnerabilities of this group. Rehabilitation and reintegration of these children should be a priority when discussing policies on vulnerable groups, so that the 2030 Development Agenda to "transform the world" actually "leaves no one behind".

\section{Referências / References}

UNHCR. Global Trends, Forced Displacement in 2018. Disponível em: https://www.unhcr.org/ globaltrends2018/

EUROSTAT, News release (71/2020). Asylum applicants considered to be unaccompanied minors, 28 April 2020.Disponível em:https://ec.europa.eu/eurostat/documents/2995521/10774034/328042020-AP-EN.pdf/03c694ba-9a9b-1a50-c9f4-29db665221a8

U.S. Customs and Border Protection, Stats and Summaries (2019). Disponível em: https://www. cbp.gov/newsroom/media-resources/stats

European Commission: European Migration Network Bulletin May 2020. Disponível em: https:// www.emn.at/wp-content/uploads/2020/05/emn-bulletin_30th-edition.pdf 